\title{
Toxic Mercury Reduction and Remediation Using Transgenic Plants with a Modified Bacterial Gene
}

\author{
Clayton L. Rugh, Gay M. Gragson, and Richard B. Meagher \\ Department of Genetics, University of Georgia, Athens, GA 30602 \\ Scott A. Merkle \\ Daniel B. Warnell School of Forest Resources, University of Georgia, Athens, GA 30602
}

\begin{abstract}
Over the last century, increasingly widespread heavy metal pollution has caused many areas to become nonarable and hazardous for both wildlife and human populations (Nriagu and Pacyna, 1988). Industrial waste products account for most heavy metal pollution, although sewage and household waste also introduce substantial levels of toxic metals into the environment. Mercury pollution is a byproduct of a number of industrial processes, and has resulted in tragic consequences in some instances (D'Itri and D'Itri, 1977). One of the most infamous cases occurred in Minamata Bay, Japan, where industrial mercury discharge into adjacent waters accumulated to lethal levels through the food chain to fish, cats, waterfowl, and humans (Harada, 1995). Population growth and rural development increase the risks of human exposure to previously isolated toxic waste sites. Cleanup costs for the highest-priority, heavy-metal polluted sites in the United States are estimated to be in excess of seven billion dollars (Russell et al., 1991). These enormous costs impede cleanup initiatives because they frequently result in lengthy litigation and encourage companies to ignore the problem. A further disincentive to cleanup is that current remediation methods, such as excavation and land-filling of contaminated soils, are temporary, ineffective, and often actually increase exposure risks. The magnitude of the heavymetal pollution problem and the immediate need for abatement and remediation call for research into alternative strategies to complement or replace current engineering approaches.
\end{abstract}

Biologically enhanced remediation has been used to assist or accelerate the cleanup of a number of contaminated sites. The use of living organisms for the degradation or extraction of toxic wastes may be applicable for sites where size, expense, or limited access may interfere with engineering-based approaches. Furthermore, biologically based remediation

Received for publication 6 Oct. 1997. Accepted for publication 8 Nov. 1997. We thank Andrew C.P. Heaton and Suzanne D. Rogers for critical reading of this manuscript. This work was supported in part by a Daniel B. Warnell School of Forest Resources Graduate Research Assistantship to C.L.R. and by a grant funded by the U.S. Dept. of Energy. The cost of publishing this paper was defrayed in part by the payment of page charges. Under postal regulations, this paper therefore must be hereby marked advertisement solely to indicate this fact. may offer the advantages of reduced incidental mobilization of pollutants, minimal site disturbance, and more rapid restoration of the rehabilitated habitat.

Our objective in this paper is to give a brief overview of the concepts and progress of microbial- and plant-assisted pollution remediation research. A summary of our efforts to genetically engineer plants for mercury reduction and detoxification, as well as considerations for future research toward this goal, will be presented. We hope to give the reader some background understanding of the limitations of and approaches used in the nascent field of phytoremediation, especially with regard to mercury pollution.

\section{BIOREMEDIATION}

Biologically based pollution treatment, or "bioremediation," is a technology that can potentially clean up a variety of toxic materials at a lower cost than standard engineering approaches. Many naturally occurring bacteria detoxify organic compounds and heavy metals. Organic compound catabolism often breaks down toxic materials into harmless products. Bacterial bioremediation may therefore provide a means for on-site treatment of organic pollutants that circumvents excavation or harsh chemical treatments (Young and Cerniglia, 1995). In addition, a number of metal-resistant bacteria have been described at the biochemical and genetic levels (Ji and Silver, 1995). Analysis of these bacterial systems has revealed multiple processes for heavymetal resistance. Known mechanisms include the efflux of toxins, such as for cellular removal of arsenic and cadmium species (Tsai et al., 1997) or detoxification by enzymatic reduction of reactive metals, such as silver and mercury, to more benign, elemental states (Silver and Phung, 1996). However, the immutable nature of heavy metal elements does not allow for their "degradation" or permanent removal by resistant bacteria, with the exception of the volatile products made by selenium- or mercury-resistant strains (Barkay et al., 1992; Cantafio et al., 1996). The use of bacteria to treat industrial waste streams in treatment tanks or on immobilized filters will allow the recovery and disposal of metal pollutants. Use of bacteria in a metal-contaminated field site would still require mechanical removal for containment of the hazard. In natural settings, bacteria are probably not effective as a permanent, large-scale solution to heavy metal contamination.

\section{PHYTOREMEDIATION}

The use of plants to stabilize, reduce, or detoxify pollution is known as "phytoremediation." The use of plants for remediation is not a novel solution to natural and man-made disturbances. Plant communities have long been used for erosion control and increased hydraulic pumping for slope and watershed stabilization (Gray and Sotir, 1996). Some plants enzymatically degrade organic pollutants and may prove important for in situ decontamination (Cunningham et al., 1996), especially in combination with microbial bioremediation strategies (Anderson and Coats, 1994). In addition, a number of plant species grow on sites rich in heavy metals (Baker and Brooks, 1989; Baker et al., 1994). Because of their natural physiological and biochemical abilities, plants are ideally suited for heavy metal removal. Their roots may penetrate extensive volumes of soil, withdrawing vast amounts of ground water and nutrients, while supplying plant debris and enabling aeration for enrichment. Furthermore, plants can use the excess electrons produced by photosystem I (Dickinson et al., 1992) for metal ion reduction, transforming the ions to less reactive, precipitable forms. Metal-accumulating plants would be far less expensive to employ than current engineering-based approaches and offer an environmentally compatible removal method (Cunningham et al., 1995).

Naturally occurring hyperaccumulating plants thrive upon and acquire in their tissues high levels of metals such as cadmium, zinc, and nickel (Reeves et al., 1995). Hyperaccumulating plants have been shown to sequester more than $1.0 \%$ of their dry mass of heavy metals from contaminated soils and have been considered a possible means for site remediation (Salt et al., 1995). However, hyperaccumulating plant species are typically slow growing, possess low biomass, and are probably of limited utility as phytoremediative crops (Baker and Brooks, 1989). Therefore, the mechanisms for hyperaccumulation are being further characterized at the physiological, biochemical, and genetic levels to enable enhancement of these abilities in established agronomic species. Manipulation of genes involved in hyperaccumulation may hasten the development of plants capable of heavy metal removal (Raskin, 1996; Stomp et al., 1993).

Bacterial heavy metal resistance also may provide genetic material used to produce metalremoving plants. Whereas the genetic pathways for hyperaccumulation in plants appear to be complex, bacterial heavy metal resis- 
tance genes are assembled in discrete operons containing small numbers of genes. The expression of such genes in transgenic plants could expedite the development of high-quality phytoremediative species. We have employed a molecular genetic approach for research on the phytoremediation of mercury contamination using a bacterial gene for ionic mercury detoxification in transgenic plants (Rugh et al., 1996).

\section{BACTERIAL BIOTRANSFORMATION OF MERCURY}

In soil, mercury occurs principally as sulfide salts (HgS), thiol organic salts ( $\mathrm{R}-\mathrm{S}-\mathrm{Hg}+$ ), and bound to carbon (R-CH2-Hg+). Sulfidebound mercury is very stable in sediments and relatively unreactive, although it is biologically and abiotically transformed to highly reactive and toxic forms of mercury. Organomercurial compounds, such as monomethylmercury (MeHg), are formed by anaerobic, sulfur-reducing bacteria and pose the most serious biological hazard (Compeau and Bartha, 1985; Gilmour et al., 1992). The relative toxicity of $\mathrm{MeHg}$ is similar to that of ionic mercury, $\mathrm{Hg}(\mathrm{II})$, but the organic forms are highly membrane permeable in animal tissues. $\mathrm{MeHg}$ is more readily retained in animal tissues and thereby biomagnified at higher trophic levels, whereas $\mathrm{Hg}$ (II) remains mostly unabsorbed and is primarily discharged through the alimentary tract (Mason et al., 1996).

Bacteria may display broad-spectrum mercury resistance by virtue of a cluster of genes comprising the mercury resistance operon (Summers, 1986). One gene of the bacterial mercury resistance operon, merB, codes for organomercurial lyase, which cleaves the carbon component from organic mercury, producing $\mathrm{Hg}$ (II). A second gene, merA, codes for mercuric ion reductase, which then converts $\mathrm{Hg}(\mathrm{II})$ to elemental mercury $\mathrm{Hg}(0)$. Elemental mercury is much less toxic than $\mathrm{Hg}$ (II) or $\mathrm{MeHg}$, is relatively chemically unreactive, and evaporates from the cells. For this reason, mercury-resistant bacteria could serve as a means of bioremediation of mercury pollution (Barkay et al., 1992). However, despite the fact that mercury-resistant bacteria account for a large proportion of the release of gaseous mercury from contaminated sites, they probably cannot be used to remediate appreciable amounts of mercury pollution in natural habitats. Mercury-resistant bacteria inhabit only a shallow depth of soil and do not prevent the release of toxic mercury by environmental forces and erosion. Measurements of current $\mathrm{Hg}(0)$ evolution rates from polluted soils have shown that complete removal of the hazard could take thousands of years (Lindberg et al., 1995), which is clearly too long to be of benefit to endangered populations.

\section{MERCURY DETOXIFICATION BY TRANSGENIC PLANTS}

The merA gene provides a potential mechanism for mercury removal and detoxification using plant genetic engineering (Rugh et al., 1996). Plants with the ability to detoxify and extract mercury would provide an attractive alternative to current expensive and less effective practices. Our initial attempts to confer $\mathrm{Hg}$ (II)-resistance to plants using the bacterial merA gene were unsuccessful (Thompson, 1990). Despite confirmation of the introduction of merA into the plant genome, no gene expression was detected and the plants remained sensitive to $\mathrm{Hg}$ (II). Characterization of the merA gene DNA sequence revealed a skewed nucleotide bias $(\approx 67 \% \mathrm{GC})$ relative to most plant genes (Barrineau et al., 1984). We hypothesized that the GC-rich DNA and uncommon codon usage of the bacterial wildtype merA were not compatible with plant gene expression and that sequence alteration would be necessary. A directed sequence mutagenesis strategy was used to develop modified merA gene constructs for transformation and analysis in plants. Overlap-extension PCR (OE-PCR) was used to create gene sequences having codon usage and nucleotide ratios more typical of highly expressed plant genes, although without altering the MerA enzyme sequence or structure. This technique is being used to modify the entire merA gene in a series of stepwise constructions that optimize $\approx 10 \%$ of DNA coding sequence per reaction.

We have developed a number of partially altered merA genes for plant genetic transformation. Arabidopsis thaliana L., a model plant for genetic manipulation, and yellow poplar (Liriodendron tulipifera L.), a fast-growing hardwood tree, were transformed with modified merA gene constructs that conferred highlevel $\mathrm{Hg}$ (II)-resistance. Transgenic Arabidopsis was developed using an Agrobacterium-based DNA transfer system and was confirmed to possess and express the merA transgene (Rugh et al., 1996). MerAArabidopsis seeds germinated, grew vigorously, flowered, and set seed on $25-100 \mathrm{~mm}$ $\mathrm{Hg}$ (II), levels normally toxic to wild-type plants. Total RNA was extracted from these plants and confirmed by northern blot analysis to possess high levels of merA mRNA in the ionic mercury-resistant lines. We measured the ability of intact seedlings to convert $\mathrm{Hg}$ (II) in an aqueous medium to elemental mercury, $\mathrm{Hg}(0)$, using a mercury vapor analyzer (Arizona Instrument, Phoenix). Transgenic plants containing modified merA evolved nearly four times the quantity of $\mathrm{Hg}(0)$ from aqueous $\mathrm{Hg}$ (II) relative to nontransformed control Arabidopsis. The relative levels of $\mathrm{Hg}(0)$ volatilization by transgenic Arabidopsis seedlings were strongly correlated with relative merA messenger RNA abundance. This correlation was consistent among our most resistant lines, indicating that even higher merA gene expression would further improve the rate of ionic mercury removal by transgenic plants.

Several different modified forms of the merA gene, including two gene constructs having $9 \%$ and $18 \%$ optimized DNA coding sequences, were transformed into embryogenic tissue cultures of yellow poplar via particle bombardment (Rugh, 1997). Independently transformed lines of yellow poplar for a number of different merA constructs were isolated on mercury selection media. PCR analysis of extracted genomic DNA confirmed these lines possessed merA transgenes. A number of these lines were regenerated into plantlets and grew on nutrient medium containing high levels of ionic mercury.

These data demonstrated that the merA genes confer mercury resistance and detoxification ability in widely divergent plant taxa. We have begun hydroponic growth experiments using merA-transformed tobacco (Nicotiana tabacum L.) and yellow poplar plants for physiological characterization of wholeplant mercury detoxification and removal. Hydroponically grown tobacco plants accumulate $\mathrm{Hg}$ (II) from the medium into their roots, but apparently do not transport or acquire $\mathrm{Hg}(\mathrm{II})$ in their aerial parts (Suszcynsky and Shann, 1995). Our hypothesis for our hydroponic experiments predicts that merAplants will be capable of removing $\mathrm{Hg}$ (II) from the medium and will reduce the amount accumulated in root tissues, relative to control plants, by conversion to volatilized $\mathrm{Hg}(0)$. The reduction of $\mathrm{Hg}$ (II) from hydroponic medium by merA-plants would provide a demonstration for a mercury phytoremediation strategy that could ultimately be used at some contaminated sites.

\section{STRATEGIES FOR MERCURY PHYTOREMEDIATION}

\section{Phytovolatilization}

Our current proposed model is that high concentrations of toxic mercury, both ionic and organic, can be reduced by merA-plants to produce gaseous $\mathrm{Hg}(0) . \mathrm{Hg}(0)$ would enter the global $\mathrm{Hg}(0)$ pool and be diluted by atmospheric air movements before redeposition at lower, more natural concentrations (Keating et al., in press). Even this idealized scenario evokes justified concerns about the efficacy and safety of intentional mercury volatilization. Clearly, such a mercury phytoremediation strategy should be carefully considered before implementation. The following example describes mercury evolution rates (just one critical parameter) for a theoretical phyto-remediation proposal at a known contaminated site. This industrially polluted wetlands contains $80,000 \mathrm{~kg}$ of $\mathrm{Hg}$ over a $130-\mathrm{km}^{2}$ range (U.S. Geological Survey, 1992), currently releasing $10 \mathrm{~kg} / \mathrm{yr}$ (Lindberg et al., 1995). The site contains $4 \mathrm{mg} \cdot \mathrm{m}^{-3} \mathrm{Hg}$ in the atmosphere at $1 \mathrm{~m}$ above ground level, $\approx 10,000$ times less than federally regulated levels of $50 \mathrm{mg} \cdot \mathrm{m}^{-3}$. If merA-plant $\mathrm{Hg}(0)$ volatilization was able to increase the rate of mercury efflux 200 -fold to $0.8 \mathrm{mg} \cdot \mathrm{m}^{-3}$, this would still be more than 50 times lower than permitted and would shorten the reclamation time to $\approx 40$ years, compared to the 8000 years required at the current rate. For sites where soil or water mercury pollution are imminent threats to wildlife habitats, population centers, or additional natural resources, the increased atmospheric $\mathrm{Hg}(0)$ release would be justified.

A major goal of mercury phytoremediation is to ensure that concentrated mercury is not simply relocated. A component of any mer- 
cury decontamination program should include meteorological and topogeographical studies to evaluate whether released $\mathrm{Hg}(0)$ will be sufficiently dispersed to avoid focused redeposition at secondary sites (Lindberg and Turner, 1988). Releasing $\mathrm{Hg}(0)$ into the atmosphere would be ineffective if the $\mathrm{Hg}(0)$ remained concentrated, such as in a valley, perhaps acquiring or depositing volatilized $\mathrm{Hg}(0)$ at still hazardous levels. Coastal areas having outward prevailing air currents would be good candidates for accelerated mercury removal through phytovolatilization. For sites having a combination of immediate hazard, unmanageably large size, and active atmospheric mixing, plant-assisted mercury volatilization may provide an effective means for reclamation. Furthermore, the construction of merA-plant communities surrounding industrial, mining, or agricultural mercury sources could prove extremely effective for preventing the accumulation of low-level, $\mathrm{Hg}$-containing effluents bound to runoff sediments. Evaporation of mercury wastes should prevent the creation of additional sites of concentrated pollution and instead release acceptably low $\mathrm{Hg}(0)$ levels at appropriate and predictable levels.

\section{Phytosequestration}

Another model for heavy metal phyto-remediation is sequestration into harvestable plant parts. Some hyperaccumulator plants store extremely high concentrations of certain heavy metals in shoots. Unfortunately, most of these plants are small, slow-growing shrubs and not suited to large-scale utilization in natural settings. A number of larger plants, such as Indian mustard (Brassica juncea L.) and sunflower (Helianthus annuus L.), acquire very high levels of toxic metal contaminants in their roots and consequently have been used for cleanup of terrestrial or aqueous pollution (Dushenkov et al., 1995; Salt et al., 1995). Ionic mercury rapidly accumulates in roots of tobacco grown in hydroponic solution (Suszcynsky and Shann, 1995). The principal shortcoming of these approaches is the difficulty of retrieving subterranean plant material as part of a large-scale phytoremediation program in natural soil environments. Extraction and sequestration of heavy metal toxins from soils will be most effective using plants that transport them to harvestable, aerial tissues.

Mercury sequestration by plant shoots may be possible by enhancement of natural properties through breeding or genetic engineering. In natural settings foliage significantly elevates atmospheric $\mathrm{Hg}(0)$ loading via evapotranspiration of root-absorbed mercury (Hanson et al., 1995; Siegel et al., 1974). Atmospheric $\mathrm{Hg}(0)$ also can enter stems and leaves, be enzymatically converted to $\mathrm{Hg}$ (II), and be retained at low levels (Suszcynsky and Shann, 1995). Although only low levels of mercury are accumulated by plant tissues, this natural ability may be augmented by introduction or manipulation of specific genes. Peroxidases and catalases can oxidize $\mathrm{Hg}(0)$ to $\mathrm{Hg}(\mathrm{II})$ in vitro (Ogata and Aikoh, 1984). Catalase activ- ity causes $\mathrm{Hg}(\mathrm{II})$ accumulation in the leaves of a wide variety of plant species (Du and Feng, 1983). Plants with elevated expression of $\mathrm{Hg}(0)$-oxidizing enzymes in shoot tissues might provide an effective vehicle for $\mathrm{Hg}$ (II)sequestration following genetic engineering. The mercury detoxification enzymes, MerA and MerB, expressed only in roots, may promote transfer of mercury from the contaminated soils through the vascular system, with tissue-specific $\mathrm{Hg}(0)$ oxidation to reactive $\mathrm{Hg}(\mathrm{II})$, and eventual storage in shoots. If the mercury could be translocated and stored in aerial parts, then collection of these tissues would provide a means of removing mercury from contaminated soils while minimizing atmospheric loading. For environmentally sensitive or populated areas, this strategy would help to reduce exposure and still allow removal of the waste. Our current research is aimed at characterizing the effect of the merA transgene on mercury movement and accumulation in plants and in developing a $\mathrm{Hg}$-sequestration phytoremediation strategy.

\section{Plant selection for mercury phytoremediation}

We developed mercury-resistant plants using Arabidopsis and yellow poplar principally because they are amenable to genetic transformation and plant regeneration. The small, shert-lived Arabidopsis is ideal for laboratory research but is of no practical utility as a phytoremediative plant. Yellow poplar is a long-lived, fast-growing forest tree and could conceivably be used in pilot or actual phytoremediation programs. However, it is not tolerant of wet soil conditions typical of many mercury polluted sites. Native plants for each particular habitat will have to be genetically engineered and examined in a controlled laboratory setting before planting for environmental cleanup. For areas where $\mathrm{Hg}(0)$ volatilization is suitable, plant "harvestability" is not an issue, and site-compatibility will be the most important criterion for plant selection. At remote wetland sites, marsh grasses such as cordgrass (genus Spartina) are among the dominant species. Spartina grows along the Atlantic coast from the northeast states to the Gulf of Mexico. It forms nearly monospecific stands of clonal patches and is invaluable for its contribution of organic matter and sand shoreline stabilization (Seneca, 1974). Spartina introduces oxygen into its rhizosphere by aerenchyma tissue function (Arenovski and Howes, 1992), which also serves to prevent the anaerobic conditions conducive to methylmercury formation (Compeau and Bartha, 1985). Tissue-culture techniques for the clonal propagation of Spartina for use in reconstructed wetlands have been reported (Rao et al., 1996). Genetic transformation of Spartina with the mercuric reductase gene could provide a."crop" for phytoremediation of mercury contaminated estuaries or marshes. Such plant populations would also serve to inhibit methylmercury formation and escape from these areas.

For sites where $\mathrm{Hg}$ sequestration is required, the need to recover aboveground parts will require large, fast-growing plants. Many tree species are capable of coppicing, or resprouting new shoots when cut. This feature could be used in well-rooted tree stands to allow periodic removal of metal-impregnated biomass. Such an application has been demonstrated with continuous growth, cutting, and resprouting of mixed willow stands (genus Salix) managed for extraction of heavy metal contaminants from sewage and sludge (RiddellBlack, 1994). Development of mercury-accumulating trees would allow establishment of long-lasting stands on contaminated sites. Coppicing would permit mercury removal while maintaining well-established root networks and minimizing erosion or other site disturbances during the restoration.

\section{CONCLUSION}

Plants have developed a wide array of strategies for transport and uptake of metal nutrients and are ideally suited to the removal of toxic metal pollutants. Plants fertilize and aerate the soil and work in combination with soil microbes to mobilize minerals from the soil medium. Hyperaccumulator plants have extraordinary metal tolerance and will help us to understand the biochemical and physiological requirements for sequestration of elevated levels of heavy metals. Regardless of whether natural hyperaccumulator species are used for phytoremediation, they will provide mechanisms that may be genetically enhanced in plants of greater agronomic utility.

Bacterial genes for heavy metal resistance and detoxification may be used to create transgenic plants capable of accumulating and detoxifying elements such as arsenic and cadmium. We used a bacterial gene for mercuric reductase to create plants that survive on and reduce toxic mercury. Mercury-resistant plants could provide an environmentally compatible option for the removal of toxic organic and ionic mercury.

Current research is investigating the use of plants for natural habitat restoration. The exceptional physiological abilities of plants could be augmented with genes from the "molecular toolboxes" of microbial metabolism to allow: the development of powerful weapons for pollution control. Such designed plant populations allow comprehensive consideration for ecological requirements, specific pollutant hazards, and human and wildlife protection.

\section{Literature Cited}

Anderson, T.A. and J.R. Coats. 1994. Bioremediation through rhizosphere technology. Amer. Chem. Soc., Washington D.C.

Arenovski, A.L. and B.L. Howes. 1992. Lacunal allocation and gas transport capacity in the salt marsh grass Spartina alterniflora. Oecologia 90:316-322.

Baker, A.J.M. And R.R. Brooks. 1989. Terrestrial higher plants which hyperaccumulate metallic elements-A review of their distribution, ecology and phytochemistry. Biorecovery 1:81-126.

Baker, A.J.M., S.P. McGrath, C.M.D. Sidoli, and R.D. Reeves. 1994. The possibility of in situ heavy metal decontamination of polluted soils using crops of metal accumulating plants. Re- 
sources, Conservation and Recycling 11:41-49.

Barkay, T., R. Turner, E. Souter, and J. Horn. 1992. Mercury biotransformations and their potential for remediation of mercury contamination. Biodegradation 3:147-159.

Barrineau, P., P. Gilbert, W.J. Jackson, C.S. Jones, A.O. Summers, and S. Wisdom. 1984. The DNA sequence of the mercury resistance operon of the IncFII plasmid NR1. J. Mol. Appl. Gen. 2:601619.

Cantafio, A.W., K.D. Hagen, G.E. Lewis, T.L. Bledsoe, K.M. Nunan, and J.M. Macy. 1996. Pilot-scale selenium bioremediation of San Joaquin drainage water with Thauera selenatis. Appl. Environ. Microbiol. 62:3298-3303.

Compeau, G.C. And R. Bartha. 1985. Sulfate-reducing bacteria: Principal methylators of mercury in anoxic estuarine sediment. Appl.Environ. Microbiol. 50:498-502.

Cunningham, S.D., T.A. Anderson, A.P. Schwab, and F.C. Hsu. 1996. Phytoremediation of soils contaminated with organic pollutants. Adv. Agron. 56:55-114.

Cunningham, S.D., W.R. Berti, and J.W. Huang. 1995. Phytoremediation of contaminated soils. Trends in Biotechnol. 13:393-397.

Dickinson, N.M., A.P. Turner, and N.W. Lepp. 1992. How do trees and other long-lived plants survive in polluted environments? Functional Ecol. 5:5-11.

D'Itri, P.A. and F.M. D'Itri. 1977. Mercury contamination: A human tragedy. Wiley-Interscience, New York.

Du, S.-H. and S.C. Feng. 1983. Catalase activity of $\mathrm{C}_{3}$ and $\mathrm{C}_{4}$ species and its relationship to mercury vapor uptake. Environ. Expt. Bot. 23:347-353.

Dushenkov, V., P.B.A. Nanda Kumar, H. Motto, and I. Raskin. 1995. Rhizofiltration: The use of plants to remove heavy metals from aqueous streams. Environ. Sci. Technol. 29:1239-1245.

Gilmour, C.C., E.A. Henry, and R. Mitchell. 1992. Sulfate stimulation of mercury methylation in freshwater sediments. Environ. Sci. Technol. 26:2281-2287

Gray, D.H. and R.B. Sotir. 1996. Biotechnical and soil bioengineering stabilization. Wiley, New York.

Hanson, P.J., S.E. Lindberg, T.A. Tabberr, J.G Owens, and K.-H. Kim. 1995. Foliar exchange of mercury vapor: Evidence for a compensation point. Water, Air, and Soil Pollution 80:373382.
Harada, M. 1995. Minamata disease: Methylmercury poisoning in Japan caused by environmental pollution. Crit. Rev. Toxicol. 25:1-24.

Ji, G. and S. Silver. 1995. Bacterial resistance mechanisms for heavy metals of environmental concern. J. Ind. Microbiol. 14:61-75

Keating, M.H., K.R. Mahaffey, and R. Shoeny. Mercury study report to congress. 452/R-96001C. U.S. Environmental Protection Agency, Washington, D.C. (In press).

Lindberg, S.E., K.-H. Kim, T.P. Meyers, and J.G. Owens. 1995. A micrometeorological gradient approach for quantifying air/surface exchange of mercury vapor: Tests over contaminated soil. Environ. Sci. Technol. 29:126-135.

Lindberg, S.E. and R.R. Turner. 1988. Factors influencing atmospheric deposition, stream export, and landscape accumulation of trace metals in forested watersheds. Water, Air, and Soil Pollution 39:123-156.

Mason, R.P., Reinfelder, J.R., and F.M.M. Morel. 1996. Uptake, toxicity, and trophic transfer of mercury in a coastal diatom. Environ. Sci. Technol. 30:1835-1845.

Nriagu, J.O. And J.M. Pacyna. 1988. Quantitative assessment of worldwide contamination of air water and soils by trace metals. Nature 333:134 139.

Ogata, M. And H. Aikoh. 1984. Mechanism of mercury oxidation in vitro by catalase and peroxidase. Biochem. Pharmacol. 33:490-493.

Rao, J.D., D.M. Seliskar, and J.L. Gallagher. 1996 In vitro shoot regeneration from callus cultures of Spartina patens, a halophytic $\mathrm{C}_{4}$ grass. Plant Physiol. 111:117. (Abstr.)

Raskin, I. 1996. Plant genetic engineering may help with environmental cleanup. Proc. Natl. Acad. Sci. USA 93:3164-3166.

Reeves, R.D., A.J.M. Baker, and R.R. Brooks. 1995 Abnormal accumulation of trace metals by plants. Mining Environ. Mgt. 3:4-8.

Riddell-Black, D.M. 1994. Heavy metal uptake by fast growing willow species, p. 145-151. In: P. Aronsson and K. Perttu (eds.). Willow vegetation filters for municipal wastewaters and sludges. Swedish Univ. Agr., Section of Energy For. Rpt. 50.

Rugh,C.L. 1997. Development of plants engineered for remediation of mercury pollution using a modified bacterial gene. $\mathrm{PhD}$ Diss., Univ. of Georgia.

Rugh, C.L., H.D. Wilde, N.M. Stack, D.M. Thomp- son, A.O. Summers, and R.B. Meagher. 1996. Mercuric ion reduction and resistance in transgenic Arabidopsis thaliana plants expressing a modified bacterial merA gene. Proc. Natl. Acad. Sci. USA 93:3182-3187.

Russell, M., E.W. Colglazier, and M.R. English. 1991. Hazardous waste remediation: The task ahead. Knoxville: Waste Mgt. Res. Educ. Inst., Univ. of Tennessee 1991:15.

Salt, D.E., M. Blaylock, N.P.B.A. Kumar, V. Dushenkov, B.D. Ensley, I. Chet, and I. Raskin. 1995. Phytoremediation: A novel strategy for the removal of toxic metals from the environment using plants. Bio/Technology 13:468-474.

Seneca, E.D. 1974. Germination and seedling response of Atlantic and Gulf coast populations of Spartina alterniflora. Amer. J. Bot. 61:947956.

Siegel, S.M., N.J. Puerner, and T.W. Speitel. 1974. Release of volatile mercury from vascular plants. Physiol. Plantarum 32:174-176.

Silver, S. and L.T. Phung. 1996. Bacterial heavy metal resistance: New surprises. Annu. Rev. Microbiol. 50:753-789.

Stomp, A.-M., K.H. Han, S. Wilbert, and M.P. Gordon. 1993. Genetic improvement of tree species for remediation of hazardous wastes. In Vitro Cellular Dev. Biol. 29P:227-232.

Summers, A.O. 1986. Organization, expression, and evolution of genes for mercury resistance. Annu. Rev. Microbiol. 40:607-634.

Suszcynsky, E.M. and J.P. Shann. 1995. Phytotoxicity and accumulation of mercury in tobacco subjected to different exposure routes. Environ. Toxicol. Chem. 14:61-67.

Thompson, D.M. 1990. Transcriptional and posttranscriptional regulation of the genes encoding the small subunit of ribulose-1,5-bisphosphate carboxylase. PhD Diss., Univ. of Georgia, Athens.

Tsai, K.J., C.-M. Hsu, and B.P. Rosen. 1997. Efflux mechanisms of resistance to cadmium, arsenic and antimony in prokaryotes and eukaryotes. Zool. Studies 36:1-16.

Young, L.Y. and C.E. Cerniglia. 1995. Ecological and applied microbiology: microbial transformation and degradation of toxic organic chemicals. Wiley-Liss, New York.

U.S. Geological Survey. 1992. Preliminary investigation of variability of mercury in sediments, Lavaca-Matagorda Bay-Estuarine system, Calhoun County, Texas. 